Discussion Paper No. 859

\title{
ARE JAPANESE HOUSEHOLDS FINANCIALLY HEALTHY, AND IF SO, WHY? A GROUP OF SEVEN (G7) COMPARISON
}

\author{
Charles Yuji Horioka
}

November 2012

The Institute of Social and Economic Research Osaka University

6-1 Mihogaoka, Ibaraki, Osaka 567-0047, Japan 


\title{
Are Japanese Households Financially Healthy, and If So, Why? A Group of Seven (G7) Comparison*
}

\author{
Charles Yuji Horioka**
}

November 25, 2012

Abstract: In this paper, I conduct an international comparison of the financial health of households using data on household wealth and indebtedness for the Group of Seven (G7) countries and show that, even though household borrowings in Japan were the highest among the G7 countries, at least until 2000, household assets were also high in Japan, as a result of which household net worth and financial health in Japan were among the highest in the G7 countries. Turning to long-term trends in Japan over time, I find that Japan has shown a sharp increase over time in household borrowing, at least until 2000, and a sharp increase over time in both household assets and household net worth, at least until 1990. It is not clear whether the greater financial health of Japanese households is due more to culture or to government policies, institutions, and other non-cultural factors, but it appears that long-term trends over time in household assets, liabilities, and net worth in Japan can be explained much better by non-cultural factors than by culture.

Key words: Financial health; households; balance sheets; liabilities; consumer credit; consumer loans; consumer finance; personal finance; indebtedness; housing loans; mortgages; borrowing; assets; financial assets; housing assets; net worth; net wealth; saving; frugality; culture; religion; tradition; traditional values; Japan; United States; Group of Seven (G7); Anglo-American credit model; Confucianism; Christianity

Journal of Economic Literature classification numbers: D12, D14, D91, E21

*I am very grateful to Lawrence Bowdish, Sheldon Garon, Andrew Gordon, Jan Logemann, the other participants of the workshop on "Cultures of Credit: Consumer Lending and Borrowing in Modern Economies," held at the German Historical Institute, Washington, D.C., on February 5-6, 2010, to Shizuka Sekita and the other participants of my graduate seminar at Osaka University for their helpful discussions and comments, to Andrew Gordon for his valuable information about data issues, and to the Japanese Ministry of Education, Culture, Sports, Science, and Technology for Grant-in-Aid for Scientific Research Category B (topic number 22330083) and Category S (topic number 20223004).

**Address for correspondence: Charles Yuji Horioka, Institute of Social and Economic Research, Osaka University, 6-1, Mihogaoka, Ibaraki, Osaka 567-0047, JAPAN, and National Bureau of Economic Research, Cambridge, Massachusetts, U.S.A. Tel.: 81-(0)6-6879-8586. Fax: 81-(0)6-6879-8583. Email: horioka@iser.osaka-u.ac.jp.

Forthcoming in The Japanese Economy, vol. 39, no. 4 (Winter 2012/13). 


\section{Introduction}

The conventional wisdom is that the Japanese and other Asians are penny pinchers and savers and that Americans and other Westerners are spendthrifts and borrowers, presumably due to differences in culture, belief systems, values, and religion (for example, the prevalence of Confucian teachings in Asia vs. the prevalence of Christian teachings in the West), but do the data bear out this conventional wisdom? The purpose of this paper is to conduct an international comparison of the financial health of households and to shed light on whether the conventional wisdom is correct using data on household wealth (assets) and indebtedness (liabilities) from the Organisation for Economic Co-operation and Development (OECD) on the Group of Seven (G7) countries (the world's seven major industrialized countries: Canada, France, Germany, Italy, Japan, the United Kingdom, and the United States). I then analyze long-term trends over time in Japan and speculate about the causes of differences among countries and of long-term trends over time in Japan.

Looking at previous analyses of this topic, the study that is closest in spirit to the present study is Horioka (2006), but it is also related to Gordon $(2006,2012)$, which explore the prevalence of consumer credit in Japan in comparison to the United States.

To summarize my main findings, I find that the conventional wisdom that the Japanese and other Asians are penny pinchers and savers and that Americans and other Westerners are spendthrifts and borrowers appears at first glance to be mistaken. The Japanese were the most prolific borrowers among the G7 countries, at least until 2000, whereas Americans were not unusually prolific borrowers. However, what matters more than the level of liabilities is the level of liabilities relative to the level of assets, and the Japanese rank relatively high with respect to both total assets and net wealth (the most comprehensive measure of household wealth that takes account of both assets and liabilities and the best indicator of the financial health of households), while Americans rank relatively low with respect to both. Thus, the Japanese are more frugal and healthier financially than Americans and most other Westerners, and the conventional wisdom is correct after all. Turning to long-term trends over time in Japan, I find that Japan has shown a sharp increase over time in household borrowing, at least until 2000, and a sharp increase over time in both household assets and household net worth, at least until 1990. It is not clear whether the greater financial health of 
Japanese households is due more to culture or to government policies, institutions, and other non-cultural factors, but it appears that long-term trends over time in household assets, liabilities, and net worth in Japan can be explained much better by non-cultural factors than by culture.

This paper is organized as follows: In section II, I present data on household wealth and indebtedness for the G7 countries; in section III, I discuss long-term trends over time in Japan; and in section IV, I summarize my conclusions and speculate about the causes of differences among countries and of long-term trends over time in Japan.

\section{Data on Household Wealth and Indebtedness for the Group of Seven (G7) Countries}

In this section, I present data on household wealth and indebtedness (at the end of the calendar year) from the Organisation for Economic Co-operation and Development (OECD) on the Group of Seven (G7) countries (the world's seven major industrialized countries: Canada, France, Germany, Italy, Japan, the United Kingdom, and the United States), taken from the OECD Economic Outlook, a semiannual publication of the OECD.

Before turning to the results, I provide definitions of the various categories of wealth and indebtedness. Household wealth or assets can be broken down into two broad categories: financial assets (consisting of bank and postal deposits, negotiable securities

such as bonds and equities, life insurance, etc.) and non-financial assets (consisting mostly of land and housing).

Similarly, household indebtedness or liabilities can be broken down into two broad categories: mortgages (housing loans) and all other liabilities. However, this breakdown is not available in some countries (France and Italy), and in these countries, loans are broken down by the period of maturity (short- and medium-term loans vs. long-term loans in France and short-term loans vs. medium- and long-term loans in Italy). For ease of exposition, I will use the term "mortgages (housing loans)" even when the data pertain to long-term or medium- and long-term loans and the term "non-housing loans" for all other liabilities, but the reader should bear in mind that the data on the breakdown of liabilities are not strictly comparable across countries. 
Finally, I use two measures of household wealth that take account of both wealth (assets) and indebtedness (liabilities) since indebtedness (liabilities) should be regarded as a negative asset or as an offset to assets. Net financial wealth is calculated as financial assets minus total liabilities, and net wealth (the broadest measure of household wealth and the best indicator of the financial health of households) is calculated as total assets minus total liabilities.

Table 1 shows data on the ratios of these various categories of household wealth and household indebtedness to household disposable income for the G7 countries for the 1980-2008 period (at 5-year intervals between 1980-2005 and also for 2008) except that data for 2007 are shown in cases in which data for 2008 are not yet available. For ease of exposition, I will say "2008” even when the data pertain to 2007.

\section{A. Data on Household Indebtedness (Liabilities)}

I look first at data on household indebtedness (liabilities). As can be seen from Table 1, what is at first surprising is that Japan (the only Asian country in the sample) ranks first with respect to the ratio of total liabilities to household disposable income in four of the seven years $(1985,1990,1995$, and 2000) and relatively high in the other years also (second in 1980 and 2005 and fourth in 2008). This ratio ranged between 77 and 135 percent in Japan during the 1980-2008 period, meaning that total liabilities exceeded household disposable income in most years!

Americans are believed to be unusually prolific borrowers, but according to Table 1, Americans are only about average with respect to the ratio of total liabilities to household disposable income, ranking between second and fifth in all seven years for which data are shown, ranking below Japan in six of the seven years, and being tied with Japan in the remaining year (1980). Thus, the conventional wisdom concerning Japan and the U.S. seems to be totally mistaken with the behavior of households in the two countries being the opposite of what it is purported to be.

Looking at the other G7 countries, the ratio of total liabilities to household disposable income is relatively high in Canada and the United Kingdom, relatively low in France and Germany, and lowest by far in Italy, with this ratio ranging from only 8 to 72 percent in Italy. Thus, there is considerable variation even among the Western 
countries, but virtually all of them rank below Japan with respect to the ratio of total liabilities to household disposable income.

I look next at the two major components of household indebtedness (liabilities) - namely, mortgages (housing loans) and non-housing loans to see which is responsible for Japan's surprisingly high liability-to-income ratio. The data in Table 1 show that the ratio of mortgages (housing loans) to household disposable income in Japan is near the bottom of the G7 countries (fifth or sixth in all seven years) and ranges from 31 to 65 percent.

By contrast, the ratio of mortgages (housing loans) to household disposable income is near the top of the G7 countries (second in most years, third in one year, and fourth in one year) in the United States and ranges from 50 to 99 percent. (Note parenthetically that this ratio increased sharply (by 30 percentage points!) during the 2000-05 period, presumably as a result of U.S. government policies to increase the availability of housing loans to the low-income, which precipitated the subprime-related financial crisis that spread from the United States to the world economy as a whole.)

Thus, the relative rankings of Japan and the United States are reversed depending on whether one looks at total liabilities or mortgages (housing loans), which suggests that the relatively high ratio of total liabilities to household disposable income in Japan is due entirely to the relatively high ratio of non-housing loans to household disposable income.

As for the other G7 countries, they have similar ranks whether one looks at total liabilities or mortgages (housing loans), with Canada and the United Kingdom ranking relatively high with respect to both, France and Germany ranking relatively low with respect to both, and Italy ranking seventh (last) in all years with respect to both.

It is not surprising that the ratio of housing loans to household disposable income is high in the United States, where there a number of governmental agencies such as the Federal Housing Association (FHA), the Federal National Mortgage Association (Fannie Mae), and the Government National Mortgage Association (Ginnie Mae) whose mandate is to increase the supply of housing loans, and in the United Kingdom, where there is little intervention in the mortgage market by the state or by state-funded entities but where there is intense competition among mutual organizations (building societies 
and credit unions) and proprietary lenders (typically banks) and little regulation to fetter that competition.

Looking next at direct evidence on the importance of non-housing loans, the data in Table 1 show that Japan ranked first with respect to the ratio of non-housing loans to household disposable income in all seven of the years for which data are shown, with this ratio ranging from 46 to 81 percent.

By contrast, the United States ranked between third and sixth, ranked lower than it did with respect to the ratio of housing loans to household disposable income in all but one year, and ranked below Japan in every year with respect to the ratio of non-housing loans to household disposable income, with this ratio ranging from 26 to 34 percent.

As for the remaining countries, the ranks of Canada, Germany, and Italy were roughly the same in the case of both housing and non-housing loans, while France and the United Kingdom ranked lower with respect to non-housing loans than they did with respect to housing loans.

In sum, Japan devotes a relatively high proportion of total consumer credit to non-housing loans (more than 50 percent except in 2008), France, Germany, the United Kingdom, and the United States devote a relatively high proportion of total consumer credit to housing loans, and Canada and Italy are somewhere in between (but the figures for France and Italy could exaggerate the importance of housing loans because all long-term loans are assumed to be housing loans in France and all medium- and long-term loans in Italy are assumed to be housing loans). Thus, contrary to the conventional wisdom, the Japanese were the most prolific borrowers among the G7 countries, at least until 2000, and they were especially prolific borrowers of non-housing loans. However, it should be noted that non-housing loans include not only non-collateralized loans used to finance consumption but also other items such the interfirm credit and trade credit of private unincorporated enterprises, which are part of the household sector. It could well be that non-housing loans are relatively more important in Japan because interfirm and trade credit are relatively more important, which in turn could be because private unincorporated enterprises are relatively more prevalent in Japan. To the extent that private unincorporated enterprises are part of the household sector, the fact that their loans are included in household liabilities is not a problem, but it should be noted that the data we present exaggerate the importance of 
non-housing loans if we are interested in salaried worker households only.

\section{B. Data on Household Wealth}

The discussion has focused until now on the ratio of indebtedness (liabilities) to household disposable income, but this can be a misleading indicator of the financial health of households because it does not take account of the opposite side of the household balance sheet-namely, household wealth (assets). A high liability-to-income ratio is not necessarily a problem if the household has a considerable amount of wealth (assets) (i.e., a high wealth-to-income ratio), and conversely, even a low liability-to-income ratio may be problematic if the household has little or no wealth (assets) (i.e., a low wealth-to-income ratio). Thus, I turn next to data on household wealth (assets).

Looking at the ratio of total assets (the broadest measure of household assets) to household disposable income in Table 1, Japan ranked first with respect to this ratio in three out of the seven years for which data are shown, second in two out of the seven years, and third in the remaining two years, with this ratio ranging from 581 to 1075 percent. Thus, Japan has a relatively high liability-to-income ratio as well as a relatively high asset-to-income ratio, so its relatively high liability-to-income ratio is not necessarily cause for concern.

By contrast, the ratio of total assets to household disposable income is relatively low in the United States, ranking between third and seventh (except in 1980, when it ranked first) and ranging from 561 to 765 percent, but the United States is about average with respect to the ratio of total liabilities to household disposable income. Thus, the situation in the United States is of more concern than that in Japan but is not necessarily cause for grave concern.

Turning to the other G7 countries, Italy and the United Kingdom rank relatively high with respect to the ratio of total assets to household disposable income while Canada, France, and Germany rank relatively low with respect to this ratio. Thus, the correlation between total liabilities and total assets is high but imperfect, with the United Kingdom ranking high with respect to both, France and Germany ranking low with respect to both, and Canada ranking high with respect to liabilities and low with respect to assets. It therefore appears that Canadians are the least healthy financially. 
Turning next to data on net wealth, which take account of assets as well as liabilities and is therefore the best indicator of the financial health of households, the ratio of net wealth to household disposable income has been relatively high in Japan, ranking between first and fourth and ranging from 504 to 943 percent. This is because although the liabilities of Japanese households are relatively high, their assets are also relatively high.

By contrast, the ratio of net wealth to household disposable income is below average in the United States, ranking between third and seventh (except in 1980, when it ranked first) and ranging from 475 to 634 percent. This is because its asset-to-income ratio is below average and its liability-to-income ratio is about average. These results show that the financial position of the Japanese is much healthier than that of Americans and are consistent with our earlier findings concerning total assets. Thus, our results suggest that the Japanese are more frugal and healthier financially than Americans and that the conventional wisdom is correct after all.

Turning to the other G7 countries, Italy and the United Kingdom rank relatively high with respect to the ratio of net wealth to household disposable income while Canada, France, and Germany rank relatively low. These results mirror the results for the asset-to-income ratio, which is not surprising because variations in the magnitude of assets exceed variations in the magnitude of liabilities. Canada's relatively low rank is consistent with our earlier finding that Canada ranks high with respect to liabilities but low with respect to assets and provides further evidence that the financial health of Canadians is not very good.

Turning finally to the share of non-financial (housing) assets in total assets, this share is relatively high in France, Germany, and Italy, and relatively low in Canada, Japan, the United Kingdom, and the United States. There does not seem to be much of a correlation between the net wealth to income ratio and the share of non-financial (housing) assets: some countries with relatively low housing shares (such as Japan and the United Kingdom) have relatively high net wealth to income ratios whereas other countries with relatively low housing shares (such as Canada and the United States) have relatively low net worth to income ratios. This suggests that portfolio choice does not have a significant impact on one's financial health. 


\section{Long-term Trends over Time in Japan}

In this section, I look at long-term trends over time in household assets, liabilities, and net worth in Japan, using the OECD data for the 1980-2008 period shown in Table 1 and the data for the 1955-1975 period shown in Table 2 and taken from the National Accounts (Kokumin Keizai Keisan) of the Economic Research Institute (Keizai Kenkyuu-sho) of the former Economic Planning Agency (Keizai Kikaku-chou) of the Japanese Government. (Unfortunately, pre-1980 data are not readily available for the other $\mathrm{G} 7$ countries.)

As can be seen from Tables 1 and 2, the ratio of total liabilities to household disposable income was only 23 percent in Japan in 1955 but increased rapidly until 1990 before leveling off at the 128-135 percent level. Thus, the Japanese were not always prolific borrowers but rather their propensity to borrow increased sharply over time, at least until 1990.

Turning to the asset side, the ratio of total assets to household disposable income was only 354 percent in Japan in 1955, increased steadily until 1990, when it peaked at 1075 percent, and has been fluctuating in the 856 to 882 percent range since then.

Turning finally to net wealth, which takes account of both assets and liabilities and is therefore the best indicator of the financial health of households, the ratio of net wealth to household disposable income, was only 331 percent in Japan in 1955, increased steadily until 1990, when it peaked at 943 percent, and has been fluctuating in the 728 to 748 percent range since then.

In sum, all three aggregates (the ratios of total liabilities, total assets, and net worth to household disposable income) have shown similar trends over time in Japan, increasing until 1990 before leveling off. What happened during the $1955-90$ period is that the increase in liabilities was more than offset by the increase in assets, as a result of which net wealth (the difference between the two) increased. Thus, the sharp increase in liabilities during this 35-year period is not a worrisome or unhealthy trend. 


\section{Conclusion}

In this paper, I conducted an international comparison of the financial health of households using data on household wealth and indebtedness for the Group of Seven (G7) countries and saw that the conventional wisdom that the Japanese and other Asians are penny pinchers and savers and that Americans and other Westerners are spendthrifts and borrowers appears at first glance to be mistaken. The Japanese were the most prolific borrowers among the G7 countries, at least until 2000, whereas Americans were not unusually prolific borrowers. However, what matters more than the level of liabilities is the level of liabilities relative to the level of assets, and the Japanese rank relatively high with respect to both total assets and net wealth (the most comprehensive measure of household wealth that takes account of both assets and liabilities and the best indicator of the financial health of households), while Americans rank relatively low with respect to both. Thus, the Japanese are more frugal and healthier financially than Americans and most other Westerners, and the conventional wisdom is correct after all.

However, the difference between Japan and the United States and other Western countries could be due to differences in culture or to differences in government policies, institutions, and other non-cultural factors. ${ }^{1}$ For example, the higher level of assets and net worth in Japan could be due to the culture of frugality in Japan or to government policies such as the availability of tax breaks for saving, government-sponsored saving promotion campaigns, and the delay in the development of social safety nets and public old-age pensions, institutions such as the large semi-annual bonuses paid to salaried workers, demographic factors such as the young age structure of the population, the early retirement age, and long life expectancy, and economic factors such as the high growth rate and high and rising land and housing prices (see Horioka $(1990,2008)$ and

\footnotetext{
1 Bowman's (2011) finding that black middle-class parents in the United States often influence their children's wealth and asset decision making suggests that culture is an important determinant of household wealth and asset accumulation behavior and that it is transmitted intergenerationally. Calder (2012), a historian, and Meyer (2012), an anthropologist, argue that household borrowing behavior is embedded in culture in the United States and Germany, respectively, but differ with respect to the immutability of culture, as discussed later. Horioka (1990), an economist, discusses the evidence on whether or not culture influences household saving behavior in Japan.
} 
Garon $(1998,2006,2011))$. Thus, it is not clear just from looking at the data which is the real culprit.

Turning to long-term trends over time in household assets, liabilities, and net worth in Japan, I found that Japan has shown a sharp increase over time in household borrowing, at least until 2000, and a sharp increase over time in both household assets and household net worth, at least until 1990.

Can these trends be explained by the culture of frugality in Japan? This depends partly on whether cultural is immutable or changes over time. Calder (2012) points out that Americans borrowed excessively even in the nineteenth century and argues that the American ethos of confidence is not new, that the ethos of thrift was never the only game in town, and that culture persists over time. By contrast, Meyer (2012) suggests that the culture of credit in Germany has changed dramatically over time, with debtors formerly viewing debts as a means of participating in a network of social obligations but with debtors nowadays viewing debt-financed consumption and instant gratification of personal desires as integral to notions of social inclusion and self-realization.

If Calder (2012) is right and traditional values change only slowly over time, the dramatic changes in household assets, liabilities, and net worth over time in Japan suggest that culture is not an important determinant of household behavior.

By contrast, if Meyer (2012) is right and traditional values erode relatively quickly over time, due, for example, to internationalization and the infiltration of foreign influences, the increase over time in household borrowing can be explained by culture but the increase over time in household assets and household net worth cannot. Moreover, the fact that the sharp increase over time in household borrowing was due largely to the sharp increase in mortgages (housing loans) suggests that factors relating to housing (such as sharply rising land and housing prices, the increased demand for housing induced by higher income levels and the rapid urbanization of the population, and the increasing availability of mortgages (housing loans)) rather than the erosion of traditional values were the primarily cause of this trend. With respect to the increasing availability of housing loans, during the high-growth era of the 1950s, 1960s, and early 1970s, the Japanese government made a conscious decision to allocate virtually all available credit to the business sector to enable it to investment in plant and equipment and to expand its productive capacity as rapidly as possible. However, the former 
Housing Loan Corporation (Juutaku Kin'yuu Kouko), whose purpose was to make low-interest housing loans to low- to middle-income households, was established by the Japanese Government in 1950 and gradually increased the supply of housing loans over time, with private financial institutions also getting a piece of the action as time went on.

Thus, whether traditional values are stable or erode relatively quickly over time, long-term trends over time in household assets, liabilities, and net worth in Japan can be explained much better by non-cultural factors than by culture.

Looking, finally, at the broader implications of my findings, what do they imply about the applicability of the "Anglo-American credit model"? My analysis found that liabilities are only about average in the United States but among the highest in the United Kingdom, which constitutes only weak evidence in favor of the conventional wisdom that Americans and the British are unusually prolific borrowers. The fact that both total assets and net wealth are relatively low (even though liabilities are relatively low) in the United States suggests that the financial position of Americans is indeed relatively weak, but the fact that both total assets and net wealth are relatively high in the United Kingdom (even though liabilities are relatively high) suggests that the financial position of the British is relatively strong. Moreover, both countries have shown dramatic but diametrically opposed changes, with the United States falling from first to last with respect to both total assets and net wealth during the 1980-2008 period but the United Kingdom rising in the ranks with respect to both during the same period. In other words, the financial health of Americans has deteriorated badly whereas the financial health of the British has improved markedly. Thus, the financial positions and trends over time of the Americans and British are dissimilar from one another but not necessarily from the other G7 countries, suggesting that there is no "Anglo-American credit model."

Is there a better way to categorize the G7 countries? In my opinion, the best criterion to use for doing so is household net wealth (the broadest measure of household wealth and the best indicator of the financial health of households). By this criterion, Italy, Japan, and the United Kingdom would end up in the relatively healthy group and Canada, France, Germany, and the United States in the relatively unhealthy group. However, it should be noted that neither of the two groups is homogenous. For example, Japan and the United Kingdom have relatively high liabilities, while Italy has 
relative low liabilities, even though they are all in the same (relatively healthy) group. Similarly, Canada and the United States have relatively high or average liabilities while France and Germany have relatively low liabilities, even though they are all in the same (relatively unhealthy) group. Thus, it can be seen that it is not easy to categorize the G7 countries and that each has its own peculiarities. This finding is not surprising because economic behavior is determined by culture, government policies, institutions, and a host of other factors.

Turning to the implications of my findings, my finding that households in Canada, France, Germany, and the United States are relatively unhealthy financially suggests that households in these countries should restrain their consumption and save more and that the governments of these countries should consider policies to encourage households to restrain their consumption and save more.

Turning finally to the limitations of this research, the fact that the comparison is limited to only the G7 countries (only one of which is non-Western) and the fact that the data on housing loans are not strictly comparable should be mentioned. I hope to overcome these limitations in my future research by expanding my sample of countries and finding more comparable data.

Another limitation of my research is that it did not place household behavior in the context of the overall macroeconomy. Even if the household sector is financially healthy, the country as a whole could be financially unhealthy if the other sectors of the economy (the government and corporate sectors) are financially unhealthy, and conversely, even if the household sector is financially unhealthy, the country as a whole could be financially healthy if the other sectors of the economy are financially healthy. For example, although Japanese households are relatively healthy financially, the government sector is relatively unhealthy financially, showing the largest government debt to GDP ratio in the developed world, and thus, the country as a whole is not in very good financial health. To put it another way, it is fortunate that the financial health of Japanese households is partly offsetting the financial distress of the government sector because the country as a whole would be in even worse financial health otherwise. Conversely, the United States is in such bad financial health overall because both the household and government sectors are in bad financial health. 


\section{References}

Bowman, Scott William (2011), "Multigenerational Interactions in Black Middle Class Wealth and Asset Decision Making," Journal of Family and Economic Issues, vol. 32, no. 1 (March), pp. 15-26.

Caldor, Lendol (2012), “ 'Ahead a Good Deal': Taking the Long View of Household Debt and Credit in American Life," in Jan Logemann, ed., The Development of Consumer Credit in Global Perspective: Business, Regulation, and Culture (Houndmills, Basingstoke, Hampshire, England: Palgrave Macmillan), pp. 257-273.

Economic Research Institute (Keizai Kenkyuu-sho), Economic Planning Agency (Keizai Kikaku-chou) (1988), ed., Report on National Accounts from 1955 to 1969 (Kokumin Keizai Keisan Houkoku: Chouki Sokyuu Suikei: Shouwa 30-nen-Shouwa 44-nen) (Tokyo, Japan: Ministry of Finance Printing Office (Ookura-shou Insatsu-kyoku)).

Economic Research Institute (Keizai Kenkyuu-sho), Economic Planning Agency (Keizai Kikaku-chou) (2000), ed., Annual Report on National Accounts (Kokumin Keizai Keisan Nenpou), 2000 edition (Tokyo, Japan: Ministry of Finance Printing Office (Ookura-shou Insatsu-kyoku)).

Garon, Sheldon (1998), Molding Japanese Minds: The State in Everyday Life (Princeton, N.J.: Princeton University Press).

Garon, Sheldon (2006), "The Transnational Promotion of Saving in Asia: "Asian Values" or the "Japanese Model"?" in Sheldon Garon and Patricia L. Maclachlan, eds., The Ambivalent Consumer: Questioning Consumption in East Asia and the West (Ithaca and London: Cornell University Press), pp. 163-187.

Garon, Sheldon (2011), Beyond Our Means: Why America Spends While the World Saves (Princeton, N.J.: Princeton University Press).

Gordon, Andrew (2006), "From Singer to Shinpan: The Growth of Consumer Credit in Japan," in Sheldon Garon and Patricia L. Maclachlan, eds., The Ambivalent Consumer: Questioning Consumption in East Asia and the West (Ithaca and London: Cornell 
University Press), pp. 137-162.

Gordon, Andrew (2012), "Credit in a Nation of Savers: The Growth of Consumer Borrowing in Japan," in Jan Logemann, ed., The Development of Consumer Credit in Global Perspective: Business, Regulation, and Culture (Houndmills, Basingstoke, Hampshire, England: Palgrave Macmillan), pp. 63-81.

Horioka, Charles Yuji (1990), "Why Is Japan's Household Saving Rate So High? A Literature Survey," Journal of the Japanese and International Economies, vol. 4, no. 1 (March), pp. 49-92.

Horioka, Charles Yuji (2006), "Are the Japanese Unique? An Analysis of Consumption and Saving Behavior in Japan," in Sheldon Garon and Patricia L. Maclachlan, eds., The Ambivalent Consumer: Questioning Consumption in East Asia and the West (Ithaca and London: Cornell University Press), pp. 113-136.

Horioka, Charles Yuji (2008), "A Survey of Household Saving Behaviour," in Florian Coulmas, Harald Conrad, Annette Schad-Seifert, and Gabriele Vogt, eds., The Demographic Challenge--A Handbook about Japan (Leiden, Netherlands: Brill Academic Publishers, 2008), pp. 879-897.

Meyer, Silke (2012), "Economic Agents and the Culture of Debt," in Jan Logemann, ed., The Development of Consumer Credit in Global Perspective: Business, Regulation, and Culture (Houndmills, Basingstoke, Hampshire, England: Palgrave Macmillan), pp. 223-241.

Organisation for Economic Co-operation and Development (OECD), ed., OECD Economic Outlook, various issues. 


\begin{tabular}{|c|c|c|c|c|c|c|c|c|c|c|c|c|c|c|}
\hline \multirow{2}{*}{$\begin{array}{ll} & \text { Country } \\
\text { Canada } & \end{array}$} & \multicolumn{2}{|l|}{1980} & \multicolumn{2}{|c|}{1985} & \multicolumn{2}{|l|}{1990} & \multicolumn{2}{|l|}{1995} & \multicolumn{2}{|l|}{2000} & \multicolumn{2}{|l|}{2005} & \multicolumn{2}{|c|}{2008} \\
\hline & & & & & & & & & & & & & & \\
\hline Net wealth & 405.0 & 5.5 & 400.7 & 4 & 416.5 & 7 & 476.5 & 6 & 502.2 & 7 & 534.5 & 7 & 544.5 & 6 \\
\hline Net financial wealth & 151.0 & 2 & 167.2 & 4 & 177.5 & 5 & 219.0 & 4 & 240.1 & 5 & 216.5 & 5 & 210.5 & 5 \\
\hline Non-financial assets & 254.0 & 5 & 233.5 & 4 & 239.0 & 6 & 257.6 & 6 & 262.0 & 6 & 318.0 & 6 & 333.9 & 6 \\
\hline Financial assets & 238.0 & 2 & 243.1 & 4 & 270.4 & 4 & 322.4 & 4 & 352.7 & 5 & 345.9 & 5 & 352.1 & 5 \\
\hline of which: Equities & 58.0 & 2 & 56.3 & 1 & 49.6 & 5 & 60.5 & 3 & 84.3 & 4 & 79.4 & 3 & 94.3 & 1 \\
\hline Total assets & 492.0 & 4 & 476.6 & 4 & 509.4 & 7 & 580.0 & 6 & 614.8 & 7 & 663.8 & 7 & 686.0 & 6 \\
\hline Share of non-fin. assets & 51.6 & 5 & 49.0 & 5 & 46.9 & 6 & 44.4 & 5 & 42.6 & 6 & 47.9 & 5 & 48.7 & 5 \\
\hline Liabilities & 87.0 & 1 & 75.9 & 4 & 92.9 & 3 & 103.4 & 3 & 112.6 & 4 & 129.4 & 4 & 141.6 & 2 \\
\hline of which: Mortgages & 53.0 & 1 & 47.4 & 3 & 59.2 & 3 & 68.8 & 2 & 69.6 & 3 & 79.1 & 3 & 88.2 & 3 \\
\hline of which: All other loans & 34.0 & 2 & 28.5 & 4 & 33.7 & 3 & 34.6 & 3 & 43.0 & 2 & 50.2 & 2 & 53.3 & 2 \\
\hline Share of mortgages & 60.9 & 5 & 62.5 & 4 & 63.7 & 5 & 66.5 & 4 & 61.8 & 5 & 61.2 & 5 & 62.3 & 5 \\
\hline \multicolumn{15}{|l|}{ France } \\
\hline Net wealth & 405.0 & 5.5 & 388.3 & 5 & 541.8 & 4 & 462.7 & 7 & 552.5 & 5 & 748.2 & 3 & 750.1 & 3 \\
\hline Net financial wealth & 85.0 & 7 & 98.4 & 7 & 169.6 & 6 & 154.2 & 6 & 205.7 & 6 & 200.5 & 6 & 185.1 & 7 \\
\hline Non-financial assets & 319.0 & 3 & 289.8 & 3 & 372.2 & 5 & 308.5 & 4 & 346.8 & 5 & 547.7 & 1 & 565.0 & 2 \\
\hline Financial assets & 147.0 & 6 & 161.7 & 6 & 248.3 & 5 & 219.8 & 7 & 282.5 & 6 & 291.5 & 6 & 285.3 & 7 \\
\hline of which: Equities & 21.0 & 5 & 43.4 & 3 & 114.1 & 1 & 53.3 & 4 & 83.5 & 5 & 77.5 & 4 & 64.5 & 5 \\
\hline Total assets & 466.0 & 6 & 451.5 & 5 & 620.5 & 4 & 528.3 & 7 & 629.3 & 6 & 839.2 & 4 & 850.3 & 4 \\
\hline Share of non.fin. assets & 68.5 & 2 & 64.2 & 1 & 60.0 & 4 & 58.4 & 3 & 55.1 & 2 & 65.3 & 1 & 66.5 & 1 \\
\hline Total liabilities & 62.0 & 4 & 63.3 & 5 & 78.7 & 5 & 65.6 & 6 & 76.8 & 6 & 91.0 & 6 & 100.2 & 6 \\
\hline of which: Long-term loans & 40.0 & 3 & 42.9 & 4 & 53.4 & 5 & 49.6 & 5.5 & 53.4 & 6 & 65.3 & 5 & 76.4 & 4 \\
\hline of which: All other loans & 22.0 & 5 & 20.4 & 5 & 25.3 & 5 & 16.0 & 6 & 23.4 & 7 & 25.7 & 7 & 23.8 & 7 \\
\hline Share of long-term loans & 64.5 & 4 & 67.8 & 2 & 67.9 & 4 & 75.6 & 1 & 69.6 & 2 & 71.8 & 3 & 76.3 & 1 \\
\hline \multicolumn{15}{|l|}{ Germany } \\
\hline Net wealth & na & na & na & na & 535.6 & 5 & 497.6 & 5 & 536.6 & 6 & 581.2 & 6 & 628.0 & 5 \\
\hline Net financial wealth & 139.0 & 3 & 172.8 & 3 & 130.8 & 7 & 126.6 & 7 & 151.4 & 7 & 180.0 & 7 & 198.0 & 6 \\
\hline Non-financial assets & na & na & na & na & 404.8 & 3 & 371.0 & 3 & 385.2 & 4 & 401.2 & 4 & 430.0 & 4 \\
\hline Financial assets & 154.0 & 5 & 189.3 & 5 & 200.7 & 7 & 223.8 & 6 & 265.9 & 7 & 287.1 & 7 & 300.0 & 6 \\
\hline of which: Equities & 7.0 & 7 & 13.3 & 7 & 11.6 & 7 & 41.2 & 6 & 75.2 & 6 & 71.3 & 7 & 72.0 & 4 \\
\hline Total assets & na & na & na & na & 605.5 & 5 & 594.8 & 5 & 651.1 & 5 & 688.4 & 6 & 730.0 & 5 \\
\hline Share of non-fin. assets & na & na & na & na & 66.9 & 1 & 62.4 & 2 & 59.2 & 1 & 58.3 & 2 & 58.9 & 3 \\
\hline Total liabilities & 15.0 & 6 & 16.5 & 6 & 70.0 & 6 & 97.2 & 4 & 114.5 & 3 & 107.2 & 5 & 102.0 & 5 \\
\hline of which: Mortgages & 10.0 & 6 & 10.4 & 6 & 53.6 & 4 & 58.7 & 4 & 71.7 & 2 & 71.0 & 4 & 69.2 & 5 \\
\hline of which: All other loans & 5.0 & 6 & 6.1 & 6 & 16.4 & 6 & 38.5 & 2 & 42.8 & 3 & 36.2 & 4 & 32.8 & 5 \\
\hline Share of mortgages & 66.7 & 2 & 63.0 & 3 & 76.6 & 1 & 60.4 & 5 & 62.6 & 4 & 66.2 & 4 & 67.8 & 4 \\
\hline \multicolumn{15}{|l|}{ Italy } \\
\hline Net wealth & 498.0 & 3 & 324.7 & 6 & 636.9 & 2 & 703.2 & 2 & 762.7 & 2 & 833.6 & 1 & 863.9 & 1 \\
\hline Net financial wealth & 109.0 & 6 & 138.5 & 6 & 196.3 & 4 & 213.9 & 5 & 329.9 & 4 & 311.2 & 3 & 298.6 & 2 \\
\hline Non-financial assets & 388.0 & 1 & 186.2 & 6 & 440.5 & 2 & 488.5 & 1 & 432.8 & 1 & 522.4 & 3 & 565.4 & 1 \\
\hline Financial assets & 118.0 & 7 & 147.8 & 7 & 225.4 & 6 & 245.5 & 5 & 382.7 & 4 & 376.4 & 4 & 370.7 & 4 \\
\hline of which: Equities & 8.0 & 6 & 14.9 & 6 & 46.0 & 6 & 37.6 & 7 & 98.0 & 3 & 84.2 & 2 & 76.8 & 3 \\
\hline Total assets & 506.0 & 3 & 334.0 & 6 & 665.9 & 3 & 734.0 & 2 & 815.5 & 3 & 898.7 & 2 & 936.0 & 2 \\
\hline Share of non-fin. assets & 76.7 & 1 & 55.7 & 3 & 66.2 & 2 & 66.6 & 1 & 53.1 & 3 & 58.1 & 3 & 60.4 & 2 \\
\hline Total liabilities & 8.0 & 7 & 9.2 & 7 & 29.1 & 7 & 31.6 & 7 & 52.8 & 7 & 647.6 & 7 & 72.1 & 7 \\
\hline $\begin{array}{l}\text { of which: Med./long-term } \\
\text { loans }\end{array}$ & 6.0 & 7 & 6.5 & 7 & 13.7 & 7 & 18.7 & 7 & 28.5 & 7 & 36.9 & 7 & 41.2 & 7 \\
\hline of which: All other loans & 2.0 & 7 & 2.7 & 7 & 15.4 & 7 & 12.9 & 7 & 24.3 & 6 & 610.7 & 6 & 35.2 & 4 \\
\hline Share of med./long-term loans & 75.0 & 1 & 70.7 & 1 & 47.1 & 6 & 59.2 & 6 & 53.9 & 6 & 5.7 & 6 & 57.2 & 6 \\
\hline Japan & & & & & & & & & & & & & & \\
\hline Net wealth & 504.0 & 2 & 561.9 & 1 & 943.2 & 1 & 735.8 & 1 & 747.7 & 3 & 740.4 & 4 & 727.8 & 4 \\
\hline Net financial wealth & 124.0 & 5 & 164.7 & 5 & 261.9 & 1 & 281.2 & 3 & 335.7 & 3 & 397.2 & 1 & 383.3 & 1 \\
\hline Non-financial assets & 380.0 & 2 & 397.3 & 1 & 681.3 & 1 & 454.6 & 2 & 411.9 & 2 & 343.2 & 5 & 344.5 & 5 \\
\hline Financial assets & 201.0 & 3 & 253.4 & 3 & 393.3 & 1 & 411.4 & 1 & 470.3 & 2 & 529.1 & 1 & 511.0 & 1 \\
\hline of which: Equities & 24.0 & 3.5 & 29.9 & 4 & 51.7 & 4 & 45.9 & 5 & 41.5 & 7 & 75.6 & 6 & 46.5 & 7 \\
\hline Total assets & 581.0 & 2 & 650.7 & 1 & 1074.6 & 1 & 866.0 & 1 & 882.2 & 2 & 872.2 & 3 & 855.5 & 3 \\
\hline Share of non-fin. assets & 65.4 & 3 & 61.1 & 2 & 63.4 & 3 & 52.5 & 4 & 46.7 & 4 & 39.3 & 6 & 40.3 & 6 \\
\hline Total liabilities & 77.0 & 2.5 & 88.8 & 1 & 131.5 & 1 & 130.2 & 1 & 134.6 & 1 & 131.9 & 2 & 127.7 & 4 \\
\hline of which: Mortgages & 31.0 & 5 & 35.6 & 5 & 50.7 & 6 & 49.6 & 5.5 & 61.1 & 5 & 64.1 & 6 & 64.7 & 6 \\
\hline of which: All other loans & 46.0 & 1 & 53.2 & 1 & 80.8 & 1 & 80.6 & 1 & 73.5 & 1 & 67.7 & 1 & 63.0 & 1 \\
\hline Share of mortgages & 40.3 & 7 & 40.1 & 7 & 38.6 & 7 & 38.1 & 7 & 45.4 & 7 & 48.6 & 7 & 50.7 & 7 \\
\hline
\end{tabular}




\begin{tabular}{|c|c|c|c|c|c|c|c|c|c|c|c|c|c|c|}
\hline \multicolumn{15}{|l|}{ Table 1 (continued) } \\
\hline U.K. & \multicolumn{2}{|c|}{1980} & \multicolumn{2}{|l|}{1985} & \multicolumn{2}{|l|}{1990} & \multicolumn{2}{|l|}{1995} & \multicolumn{2}{|c|}{2000} & \multicolumn{2}{|c|}{2005} & \multicolumn{2}{|l|}{2008} \\
\hline Net wealth & 431.0 & 4 & 491.2 & 2 & 611.0 & 3 & 568.7 & 3 & 768.1 & 1 & 827.0 & 2 & 759.6 & 2 \\
\hline Net financial wealth & 133.0 & 4 & 179.2 & 2 & 214.1 & 3 & 288.5 & 2 & 380.3 & 1 & 304.3 & 4 & 242.8 & 4 \\
\hline Non-financial assets & 297.0 & 4 & 312.0 & 2 & 396.9 & 4 & 280.1 & 5 & 387.8 & 3 & 522.7 & 2 & 516.8 & 3 \\
\hline Financial assets & 190.0 & 4 & 265.0 & 2 & 329.9 & 3 & 394.8 & 3 & 497.4 & 1 & 466.6 & 2 & 424.3 & 2 \\
\hline of which: Equities & 24.0 & 3.5 & 26.7 & 5 & 61.2 & 2 & 78.3 & 2 & 113.6 & 2 & 76.0 & 5 & 50.1 & 6 \\
\hline Total assets & 487.0 & 5 & 577.0 & 2 & 726.8 & 2 & 674.9 & 3 & 885.2 & 1 & 989.3 & 1 & 941.0 & 1 \\
\hline Share of non-fin. assets & 61.0 & 4 & 54.1 & 4 & 54.6 & 5 & 41.5 & 6 & 43.8 & 5 & 52.8 & 4 & 54.9 & 4 \\
\hline Total liabilities & 57.0 & 5 & 85.8 & 2 & 115.8 & 2 & 106.3 & 2 & 117.1 & 2 & 162.3 & 1 & 181.4 & 1 \\
\hline of which: Mortgages & 33.0 & 4 & 52.3 & 1 & 81.3 & 1 & 78.3 & 1 & 85.4 & 1 & 121.2 & 1 & 137.3 & 1 \\
\hline of which: All other loans & 24.0 & 4 & 33.5 & 2 & 34.5 & 2 & 28.0 & 5 & 31.7 & 5 & 41.1 & 3 & 44.1 & 3 \\
\hline Share of mortgages & 57.9 & 6 & 61.0 & 6 & 70.2 & 2 & 73.7 & 2 & 72.9 & 1 & 74.7 & 1 & 75.7 & 2 \\
\hline \multicolumn{15}{|l|}{ U.S.A. } \\
\hline Net wealth & 507.0 & 1 & 478.7 & 3 & 474.5 & 6 & 509.3 & 4 & 579.4 & 4 & 634.1 & 5 & 489.7 & 7 \\
\hline Net financial wealth & 259.0 & 1 & 251.9 & 1 & 259.0 & 2 & 302.0 & 1 & 355.5 & 2 & 335.3 & 2 & 256.7 & 3 \\
\hline Non-financial assets & 248.0 & 6 & 226.8 & 5 & 215.6 & 7 & 207.6 & 7 & 223.9 & 7 & 298.8 & 7 & 233.0 & 7 \\
\hline Financial assets & 336.0 & 1 & 332.0 & 1 & 345.6 & 2 & 395.4 & 2 & 456.2 & 3 & 466.4 & 3 & 388.3 & 3 \\
\hline of which: Equities & 61.0 & 1 & 48.2 & 2 & 52.1 & 3 & 105.1 & 1 & 148.9 & 1 & 127.6 & 1 & 86.3 & 2 \\
\hline Total assets & 584.0 & 1 & 558.8 & 3 & 561.2 & 6 & 603.0 & 4 & 680.1 & 4 & 765.2 & 5 & 621.2 & 7 \\
\hline Share of non-fin. assets & 42.5 & 6 & 40.6 & 6 & 38.4 & 7 & 34.4 & 7 & 32.9 & 7 & 39.0 & 7 & 37.5 & 7 \\
\hline Total liabilities & 77.0 & 2.5 & 80.1 & 3 & 86.6 & 4 & 93.4 & 5 & 100.7 & 5 & 131.1 & 3 & 131.6 & 3 \\
\hline of which: Mortgages & 50.0 & 2 & 49.5 & 2 & 60.3 & 2 & 63.2 & 3 & 67.2 & 4 & 97.5 & 2 & 98.9 & 2 \\
\hline of which: All other loans & 27.0 & 3 & 30.6 & 3 & 26.3 & 4 & 30.2 & 4 & 33.4 & 4 & 33.6 & 5 & 32.7 & 6 \\
\hline Share of mortgages & 64.9 & 3 & 61.8 & 5 & 69.6 & 3 & 67.7 & 3 & 66.8 & 3 & 74.3 & 2 & 75.1 & 3 \\
\hline
\end{tabular}

Notes: The left-hand figures show the ratio of each category of assets or liabilities (at the end of the year) to net household disposable income (in percent). The figures pertain to the household sector inclusive of non-profit institutions serving households except in the case of Italy. The right-hand figures show the rank of each country among the Group of Seven countries.

Source: OECD Economic Outlook, no. 54 (December 1993), Table A-64, for 1980 data; no. 65 (June 1999), Annex Table 58 of the same source for 1985 data; vol. 2002/2, no. 72 (December 2002), Annex Table 56 of the same source for 1990 data; vol. 2007/2, no. 82 (December 2007), Annex Table 58 of the same source for 1995 data; and vol. 2009/2, no. 86 (November 2009), Annex Table 58 of the same source for 2000, 2005, and 2008 data. 
Table 2: House hold Wealth and Indebtedness in Japan, 1955-75

\begin{tabular}{|l|r|r|r|r|r|}
\hline & \multicolumn{1}{|c|}{1955} & \multicolumn{1}{|c|}{1960} & \multicolumn{1}{|c|}{1965} & \multicolumn{1}{c|}{1970} & \multicolumn{1}{|c|}{1975} \\
\hline Net wealth & 330.9 & 363.6 & 332.6 & 398.8 & 415.4 \\
\hline Net financial wealth & 56.9 & 75.4 & 77.8 & 97.1 & 98.9 \\
\hline Non-financial assets & 274.0 & 288.2 & 254.8 & 301.6 & 316.5 \\
\hline Financial assets & 79.6 & 114.8 & 131.5 & 157.2 & 161.2 \\
\hline of which: Equities & 9.5 & 13.0 & 14.8 & 24.0 & 20.1 \\
\hline Total assets & 353.6 & 403.0 & 386.3 & 458.8 & 477.7 \\
\hline Total liabilities & 22.7 & 39.4 & 53.7 & 60.0 & 62.3 \\
\hline
\end{tabular}

Note: The figures show the ratio of each category of assets and liabilities (at the end of the year) to net household disposable income (in percent). The figures for 1955-65 pertain to the household sector inclusive of private non-profit institutions serving households whereas the figures for 1970 and 1975 pertain to the household sector exclusive of private non-profit institutions serving households.

Sources: Economic Research Institute (Keizai Kenkyuu-sho), Economic Planning Agency (Keizai Kikaku-chou), ed., Report on National Accounts from 1955 to 1969 (Kokumin Keizai Keisan Houkoku: Chouki Sokyuu Suikei: Shouwa 30-nen--Shouwa 44-nen) (Tokyo, Japan: Ministry of Finance Printing Bureau (Ookura-shou Insatsu-kyoku), 1988) for 1955-65 data; Economic Research Institute (Keizai Kenkyuu-sho), Economic Planning Agency (Keizai Kikaku-chou), ed., Annual Report on National Accounts (Kokumin Keizai Keisan Nenpou), 2000 edition (Tokyo, Japan: Ministry of Finance Printing Bureau (Ookura-shou Insatsu-kyoku), 2000) for 1970-75 data. 